\title{
Article \\ Effect of Nitrate/Bromide on the Hydration Process of Cement Paste Mixed with Alkali Free Liquid Accelerator at Low Temperature
}

\author{
Yongdong $\mathrm{Xu}^{1,2, *(1)}$ and Tingshu $\mathrm{He}^{1, *}$ \\ 1 College of Materials Science and Engineering, $\mathrm{Xi}^{\prime}$ an University of Architecture and Technology, \\ Xi'an 710055, China \\ 2 School of Chemwastry and Chemical Engineering, Ankang University, Ankang 725000, China \\ * Correspondence: aku_xyd@aku.edu.cn (Y.X.); hetingshu@xauat.edu.cn (T.H.)
}

Citation: Xu, Y.; He, T. Effect of Nitrate/Bromide on the Hydration Process of Cement Paste Mixed with Alkali Free Liquid Accelerator at Low Temperature. Crystals 2021, 11, 1585. https://doi.org/10.3390/

cryst11121585

Academic Editors: Dawei Wang and Hui Yao

Received: 21 November 2021

Accepted: 7 December 2021

Published: 19 December 2021

Publisher's Note: MDPI stays neutral with regard to jurisdictional claims in published maps and institutional affiliations.

Copyright: (C) 2021 by the authors. Licensee MDPI, Basel, Switzerland. This article is an open access article distributed under the terms and conditions of the Creative Commons Attribution (CC BY) license (https:/ / creativecommons.org/licenses/by/ $4.0 /)$.

\begin{abstract}
The effects of different inorganic salt accelerators $\left(\mathrm{CaBr}_{2}, \mathrm{NaBr}, \mathrm{Ca}\left(\mathrm{NO}_{3}\right)_{2}, \mathrm{NaNO}_{3}\right)$ and an alkali-free liquid accelerator were researched at a low temperature of $10{ }^{\circ} \mathrm{C}$. The results showed the effects of $1.5 \% \mathrm{NaBr}$ and $1.5 \% \mathrm{NaNO}_{3}$ inorganic accelerator were pronounced. The $1-\mathrm{d}$ compressive strengths of the mortar with these two inorganic salts were increased by $185.8 \%$ and $184.2 \%$, respectively, and the final setting times were shortened from 7.74 to $6.08 \mathrm{~min}$ and $6.12 \mathrm{~min}$, respectively. The hydration temperatures at $10{ }^{\circ} \mathrm{C}$ were measured, and the promotion effects of the inorganic accelerators were calculated: the relationship between the hydration degree was $\alpha_{\mathrm{AS}}+\mathrm{NN}>\alpha_{\mathrm{AS}}+\mathrm{NB}$ $>\alpha_{\mathrm{AS}+\mathrm{CB}}>\alpha_{\mathrm{AS}+\mathrm{CN}}>\alpha_{\mathrm{AS}}$. In addition, the reaction of $\mathrm{C}_{3} \mathrm{~A}$ with $\mathrm{NaBr}$ and $\mathrm{NaNO}_{3}$ was used to analyze the products in an ettringite phase, i.e., $\mathrm{Ca}_{4} \mathrm{Al}_{2} \mathrm{O}_{6} \mathrm{Br}_{2} 10 \cdot \mathrm{H}_{2} \mathrm{O}, 3 \mathrm{CaOAl}{ }_{2} \mathrm{O}_{3} \mathrm{Ca}\left(\mathrm{NO}_{3}\right)_{2} \mathrm{X} \cdot \mathrm{H}_{2} \mathrm{O}$. The formation of these phases was detected in the hydration products of the cement paste hydration for $12 \mathrm{~h}, 24 \mathrm{~h}$, and $28 \mathrm{~d}$. Combined with the mass loss of the ettringite phase at $90-120{ }^{\circ} \mathrm{C}$, determined using TG/DTG, the synergetic acceleration mechanism of the inorganic accelerators was comprehensively inferred.
\end{abstract}

Keywords: acceleration; ettringite phase; low temperature; mechanism

\section{Introduction}

Shotcretes have been widely used in tunnel and mine construction. It has the advantages of a fast setting time and a high early strength, speeding up the construction process [1,2]. Among these, an accelerator is an integral part of shotcrete to accelerate the hydration of cement to achieve these characteristics [3-5]. However, although shotcrete has the characteristics of rapid setting and early strength, its early compressive strength development depends on ambient temperature, just like ordinary concrete. For ordinary concrete, when the average temperature is higher than $20^{\circ} \mathrm{C}$, the compressive strength of the concrete develops well; however, when the temperature is lower than $10{ }^{\circ} \mathrm{C}$, the strength of the concrete decreases and the curing cycle is prolonged [6]. For ordinary concrete, many researchers used chemical admixtures to promote low-temperature hydration to improve early strength development. Presently, the early strength of concrete is improved by accelerating the hydration of tricalcium silicate. Some researchers have summarized the relationship between different ions and cement hydration. The promotion effect of different anions and cations on hydration is as follows [7-10]: anions: $\mathrm{Br}^{-}>\mathrm{Cl}^{-}>$ $\mathrm{SCN}^{-}>\mathrm{I}^{-}$; cations: $\mathrm{Ca}^{2+}>\mathrm{Sr}^{2+}>\mathrm{Ba}^{2+}>\mathrm{Na}^{+}$.

Similarly, for shotcrete, an alkali-free accelerator could shorten the setting time and improve the early compressive strength, and environmental temperatures have a significant effect on it. At present, research on the influence of ambient temperature on the mechanical properties of shotcrete mainly focuses on the influence of high-temperature environments; the Niu research group mainly focuses on the influence of high-temperature environments on the mechanical properties of shotcrete [11]. 
However, there is little research on the effects of low-temperature environments on the performance of shotcrete. For low temperature $\left(<20^{\circ} \mathrm{C}\right)$, the reaction rate of cement clinker is reduced [12]. The influence of the environmental temperature on the cement hydration is directly reflected in the performance of the accelerator, such as initial and final setting times and early strength. In addition, as an alkali-free liquid accelerator contains many aluminum ions, sulfate ions, and a small number of polyol amines, sensitive of the system, if early-strength inorganic salts are added to the accelerator, the precipitation phenomenon often occurs. Therefore, we propose to use the synergetic effect of inorganic salt accelerators to solve the problems of shotcrete in a low-temperature environment to reduce the occurrence of events that affect the shotcrete construction due to low ambient temperature. The selection of inorganic salt early-strength agents was performed based on the research of relevant scholars on inorganic salt early-strength agents, as shown in Table 1.

Table 1. Summary of the related effects of inorganic salt early-strength agents in the literature.

\begin{tabular}{cccccc}
\hline References & Types of Inorganic Salts & $\begin{array}{c}\text { Ambient } \\
\text { Temperature }\end{array}$ & Dosage & $\begin{array}{c}\text { Compressive } \\
\text { Strength (24 h) }\end{array}$ & Types \\
\hline Zhang et al. [13] & $\mathrm{CaBr}_{2}$ & $5{ }^{\circ} \mathrm{C}$ & $1 \%$ & $10.9 \mathrm{MPa}$ & $\mathrm{Cement} \mathrm{pastes}$ \\
Bao et al. [14] & $\mathrm{C}_{2} \mathrm{H}_{2} \mathrm{CaO}_{4}$ & $5{ }^{\circ} \mathrm{C}$ & $1 \%$ & $3.7 \mathrm{MPa}$ & $\mathrm{C} 40 \mathrm{concrete}$ \\
Shi et al. [15] & $\mathrm{A}+\mathrm{B}+\mathrm{Ca}\left(\mathrm{NO}_{3}\right)_{2}$ & $20^{\circ} \mathrm{C}$ & $2.1 \%$ & $41.0 \mathrm{MPa}$ & $\mathrm{Mortar}$ \\
Wang et al. [16] & $\mathrm{ZL}-1$ & $8{ }^{\circ} \mathrm{C}$ & $6 \%$ & $5.7 \mathrm{MPa}$ & $\mathrm{Cement} \mathrm{stone}$ \\
Lee et al. [17] & $\mathrm{CaBr}_{2}+\mathrm{NaSCN}+\mathrm{DEA}$ & $10^{\circ} \mathrm{C}$ & $0.5 \%$ & $5.0 \mathrm{MPa}$ & $\mathrm{Concrete}$ \\
Zou et al. [18] & $\mathrm{LiAl-LDHs}$ & $-10{ }^{\circ} \mathrm{C}$ & $1.5 \%$ & $25.0 \mathrm{MPa}$ & $\mathrm{Cement} \mathrm{stone}$ \\
Yoneyama et al. [19] & $\mathrm{Ca}\left(\mathrm{NO}_{3}\right)_{2}$ & $-10^{\circ} \mathrm{C}$ & $13 \%$ & $7.0 \mathrm{MPa}$ & $\mathrm{Concrete}$ \\
Kim et al. [20] & $\mathrm{Ca}\left(\mathrm{NO}_{3}\right)_{2}$ & $10^{\circ} \mathrm{C}$ & $8 \%$ & $7.6 \mathrm{MPa}$ & Mortar \\
Liu et al. [21] & $\mathrm{CaCl}{ }_{2}$ & $5{ }^{\circ} \mathrm{C}$ & $1.5 \%$ & $7.0 \mathrm{MPa}$ & Cement mortars \\
\hline
\end{tabular}

For inorganic salt early-strength agents, they mainly react with $\mathrm{C}_{3} \mathrm{~A}$ to form a calcium aluminate-like $\mathrm{AFt}$ phase, such as $\mathrm{CaBr}{ }_{2}$, and $\mathrm{Ca}\left(\mathrm{NO}_{3}\right)_{2}$ reacts with $\mathrm{C}_{3} \mathrm{~A}$ to form bromo aluminate calcium hydrate $\left(\mathrm{Ca}_{4} \mathrm{Al}_{2} \mathrm{O}_{6} \mathrm{Br}_{2} \cdot 10 \mathrm{H}_{2} \mathrm{O}\right)$ and nitrate hydrates (nitrate$\left.\mathrm{AFm} ; 3 \mathrm{CaO} \cdot \mathrm{Al}_{2} \mathrm{O}_{3} \cdot \mathrm{Ca}\left(\mathrm{NO}_{3}\right)_{2} \cdot \mathrm{XH}_{2} \mathrm{O}\right)[13,19,20,22,23]$. The literature shows that they have better early strength properties in a low-temperature environment for ordinary concrete.

Therefore, whether those kinds of early strength agent could produce a synergetic effect with an alkali-free liquid accelerator, improving the early strength of concrete in a low-temperature environment, and solve the influence of the low-temperature environment on the mechanical properties of shotcrete. Therefore, the effect of different kinds of nitrate and bromide (calcium bromide, sodium bromide, calcium nitrate, and sodium nitrate) on the strength of mortar mixed with an accelerator system was researched to reveal the mechanism of inorganic salt, promoting the strength development in a low-temperature environment.

\section{Materials and Experimental Program}

\subsection{Raw Materials}

Ordinary Portland cement was used in the experiment, and the relevant chemical composition and parameters are shown in Table 2. Table 3 shows the chemical composition and the related performance indexes of an alkali-free liquid accelerator. The chemical reagents used in the experiment were analytical reagents.

Table 2. Chemical composition of cement.

\begin{tabular}{ccccccccc}
\hline $\begin{array}{c}\text { Chemical } \\
\text { Composition }\end{array}$ & $\mathrm{SiO}_{2}$ & $\mathrm{Al}_{2} \mathrm{O}_{3}$ & $\mathrm{Fe}_{2} \mathrm{O}_{3}$ & $\mathrm{CaO}$ & $\mathrm{MgO}$ & $\mathbf{R}_{2} \mathbf{O}$ & $\mathrm{SO}_{3}$ & Loss \\
\hline Cement $(\mathrm{wt} \%)$ & 21.3 & 5.96 & 3.36 & 60.31 & 2.7 & 0.83 & 1.72 & 2.12 \\
\hline
\end{tabular}


Table 3. Physical and chemical indexes related to the accelerator performance.

\begin{tabular}{ccccccc}
\hline $\begin{array}{c}\text { Accelerator } \\
\text { Category }\end{array}$ & $\begin{array}{c}\text { Solid } \\
\text { Content (\%) }\end{array}$ & $\mathbf{p H}$ & $\begin{array}{c}\text { Initial Setting } \\
\text { Time (s) }\end{array}$ & $\begin{array}{c}\text { Final Setting } \\
\text { Time (s) }\end{array}$ & \multicolumn{2}{c}{$\begin{array}{c}\text { Compressive } \\
\text { Strength (MPa) }\end{array}$} \\
\hline $\begin{array}{l}\text { Alkali-free } \\
\text { accelerator }\end{array}$ & $40 \%$ & $3-4$ & 150 & 345 & $\mathbf{1 ~ d ~}$ & $\mathbf{2 8 ~ d}$ \\
\hline
\end{tabular}

Note: The test method in the table was carried out according to the standard GB-T 35159-2017, in which the dosage of the alkali-free accelerator was $7 \%$.

\subsection{Specimen Preparation and Mix Proportions}

The mixing water-cement $(\mathrm{W} / \mathrm{C})$ ratio was 0.50 , the dosage of the alkali-free liquid accelerator was $7 \%$ of the cement mass, and the sample size was $40 \mathrm{~mm} \times 40 \mathrm{~mm} \times 160 \mathrm{~mm}$ according to the requirements of accelerator for shotcrete (GB/T 35159-2017). The mixing amount of inorganic salt was also carried out according to the percentage of cement quality, and the specific mixing design proportions are shown in Table 4.

Table 4. Mixing design proportions.

\begin{tabular}{cccccccc}
\hline Mix ID & $\begin{array}{c}\text { Cement } \\
(\mathbf{g})\end{array}$ & $\begin{array}{c}\mathrm{CaBr}_{\mathbf{2}} \\
\mathbf{( \% )}\end{array}$ & $\begin{array}{c}\mathbf{N a B r} \\
\mathbf{( \% )}\end{array}$ & $\begin{array}{c}\mathrm{Ca}\left(\mathbf{N O}_{3} \mathbf{2}_{2}\right. \\
\mathbf{( \% )}\end{array}$ & $\begin{array}{c}\mathbf{N a N O}_{3} \\
\mathbf{( \% )}\end{array}$ & $\begin{array}{c}\text { Water } \\
\mathbf{( g )}\end{array}$ & $\begin{array}{c}\text { Alkali-Free } \\
\text { Accelerator } \\
\mathbf{( g )}\end{array}$ \\
\hline AS & 900 & - & - & - & - & 412.2 & 63 \\
AS-CB1.0 & 900 & $1.0 \%$ & - & - & - & 412.2 & 63 \\
AS-CB1.5 & 900 & $1.5 \%$ & - & - & - & 412.2 & 63 \\
AS-CB2.0 & 900 & $2.0 \%$ & - & - & - & 412.2 & 63 \\
AS-NB1.0 & 900 & - & $1.0 \%$ & - & - & 412.2 & 63 \\
AS-NB1.5 & 900 & - & $1.5 \%$ & - & - & 412.2 & 63 \\
AS-NB2.0 & 900 & - & $2.0 \%$ & - & - & 412.2 & 63 \\
AS-CN1.0 & 900 & - & - & $1.0 \%$ & - & 412.2 & 63 \\
AS-CN1.5 & 900 & - & - & $2.0 \%$ & - & 412.2 & 63 \\
AS-CN2.0 & 900 & - & - & $3.0 \%$ & - & 412.2 & 63 \\
AS-NN1.0 & 900 & - & - & - & $1.0 \%$ & 412.2 & 63 \\
AS-NN1.5 & 900 & - & - & - & $1.5 \%$ & 412.2 & 63 \\
AS-NN2.0 & 900 & - & - & - & $2.0 \%$ & 412.2 & 63 \\
\hline
\end{tabular}

Note: $\mathrm{CaBr}_{2}, \mathrm{NaBr}, \mathrm{Ca}\left(\mathrm{NO}_{3}\right)_{2}, \mathrm{NaNO}_{3}$, and the alkali-free accelerator are abbreviated as $\mathrm{CN}, \mathrm{NB}, \mathrm{CN}, \mathrm{NN}$, and AS, respectively.

\subsection{Mixed $C_{3} A$ and Inorganic Salt Solution}

The inorganic salt solution was mixed with $\mathrm{C}_{3} \mathrm{~A}$ to prepare the calcium aluminate phase material. The mixing procedures were described as follows: $3 \mathrm{~g}$ of $\mathrm{NB}$ and $\mathrm{NN}$ each were dissolved in $30 \mathrm{~g}$ of water $\left(10^{\circ} \mathrm{C}\right)$ separately. The respective solutions were stirred for $2 \mathrm{~min}$, placed in a low-temperature test chamber for $24 \mathrm{~h}$, washed with deionized water. Hydration was terminated with isopropanol for $24 \mathrm{~h}$. Then, these two solutions were filtered and vacuum-dried for $48 \mathrm{~h}$ to obtain bromide- $C_{3} \mathrm{~A}$ and nitrate- $\mathrm{C}_{3} \mathrm{~A}$ reactants, respectively. Detection and analysis were carried out respectively.

\subsection{Testing of Samples}

\subsubsection{Setting Time}

The test method for initial and final setting time was described as follows: water, cement, and the accelerators were pre-cooled at $10 \pm 0.5{ }^{\circ} \mathrm{C}$ for $24 \mathrm{~h}$. The setting times were tested with the Vicat apparatus. Refer to GB/T 35159-2017 for specific test steps, and the addition amounts of inorganic salts are shown in Table 5. 
Table 5. Setting time test design proportions.

\begin{tabular}{ccc}
\hline Water/Binder Ratio & $\begin{array}{c}\text { Composition of } \\
\text { the Slurry }\end{array}$ & The Dosage of Inorganic Salts \\
\hline & & $1 \% \mathrm{CaBr}_{2} / 1.5 \% \mathrm{CaBr}_{2} / 2.0 \% \mathrm{CaBr}_{2}$ \\
& & $1 \% \mathrm{NaBr} / 1.5 \% \mathrm{NaBr} / 2.0 \% \mathrm{NaBr}$ \\
& $\mathrm{Cement}+7 \% \mathrm{AS}$ & $1 \% \mathrm{Ca}\left(\mathrm{NO}_{3}\right)_{2} / 1.5 \% \mathrm{Ca}\left(\mathrm{NO}_{3}\right)_{2} / 2.0 \% \mathrm{Ca}\left(\mathrm{NO}_{3}\right)_{2}$ \\
& $1 \% \mathrm{NaNO}_{3} / 1.5 \% \mathrm{NaNO}_{3} / 2.0 \% \mathrm{NaNO}_{3}$ \\
\hline
\end{tabular}

\subsubsection{Heat of Hydration}

According to the proportions in Table 4, the cement paste was prepared, placed in a measuring bottle and placed in a $10 \pm 0.5^{\circ} \mathrm{C}$ incubator to measure the hydration heat release. The test time was $24 \mathrm{~h}$, and the temperature collection interval was $10 \mathrm{~s}$. The test diagram is shown in Figure 1.
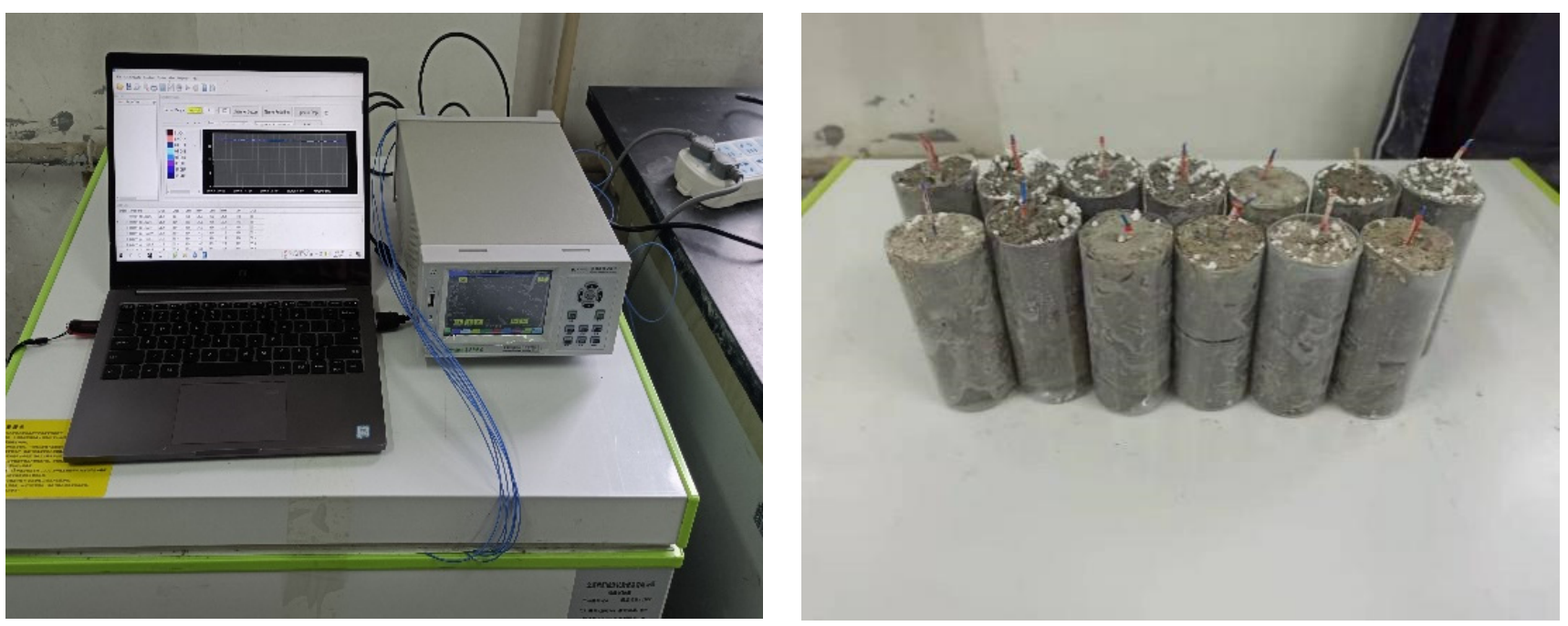

Figure 1. Hydration temperature testing device and test samples.

\subsubsection{Compressive Strength}

The temperatures of the specimens were $10 \pm 0.5^{\circ} \mathrm{C}$ with the corresponding ages of $1,3,7$, and $28 \mathrm{~d}$. When the specimens reached the corresponding age, the compressive strength of the cement mortar was tested on a compression testing machine. Control the speed of cement mortar press was controlled to be $2.4 \mathrm{KN} / \mathrm{s}$, and the compression test of the test block was carried out.

\subsubsection{Microstructure Analysis}

The cement and water were pre-cooled at $10 \pm 0.5^{\circ} \mathrm{C}$ for $24 \mathrm{~h}$, according to the waterbinder ratio of 0.5 , molds were installed, and a digital thermometer was used to measure the heat release of the cement. The composition of the hydrated products was determined by Dwascovery TGA 5500, temperature range of 30 to $1000^{\circ} \mathrm{C}$, heating rate $20^{\circ} \mathrm{C} / \mathrm{min}$ in a pure nitrogen atmosphere. The $\mathrm{XRD}$ analysis characterized the hydration products, the scanning angle range was $5-80^{\circ} \mathrm{C}$, and the scanning rate was $10^{\circ} \mathrm{C} / \mathrm{min}$.

\section{Experimental Results}

\subsection{Setting Time at Low Temperature}

The influences of inorganic salts on the setting time of the alkali-free liquid accelerator cement paste at low temperature were explored. In Figure 2, the initial setting and the final setting of the cement paste with $7 \%$ AS were 2.3 and $7.47 \mathrm{~min}$, respectively under the environment of $10^{\circ} \mathrm{C}$. When the inorganic salts $\mathrm{CB}, \mathrm{NB}, \mathrm{NN}$, and $\mathrm{CN}$ were added 
to the pastes at the dosage of $1.0 \%, 1.5 \%$, and $2.0 \%$, the results showed that the initial setting time ratio was less than that of the control group (AS) and the influences of the dosage and type of inorganic salts on the initial setting time were almost unchanged. It could be seen that inorganic salts had little effect on the initial setting time under a low-temperature environment. However, the effects of inorganic salts on the final setting time were remarkable. The data showed that the four inorganic salts could shorten the final setting time at different dosages, of which $1.5 \% \mathrm{NB}$ and $1.5 \% \mathrm{NN}$ could control the final setting times at 6.08 and $6.12 \mathrm{~min}$, respectively. Generally, the hydration process of cement is mainly related to the temperature. The temperature affects activation energy and thus cement hydration [24,25]. Inorganic salts promote cement hydration at low temperature. Therefore, it is necessary to understand further the effects of inorganic salts on low-temperature hydration, such as hydration temperature and compressive strength.

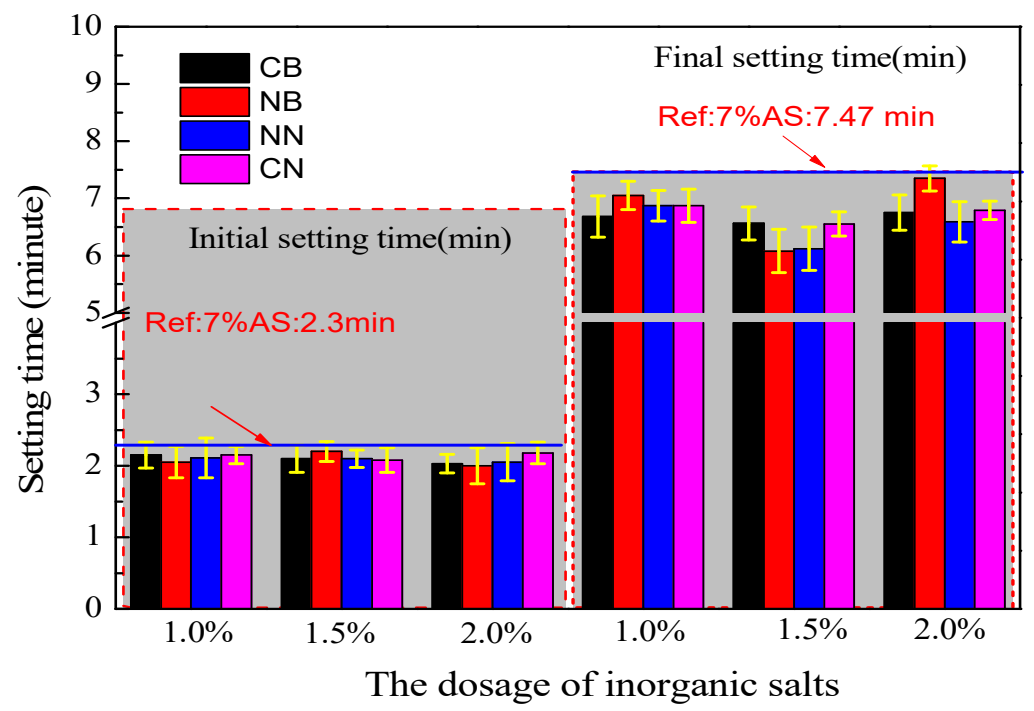

Figure 2. Effects of inorganic salts on setting time at low temperature.

\subsection{Compressive Strength at Low Temperature}

Figure 3A shows the influences of different inorganic salt contents on the 1-d compressive strength of the alkali-free accelerator mortar. The 1-d compressive strength of mortar without inorganic salts was 4.86 MPa, while the Chinese standard GB/T 35159-2017 required that the compressive strength of the mortar was $8.0 \mathrm{MPa}$, which was $39.25 \%$ lower than the standard. If the construction was carried out at $10^{\circ} \mathrm{C}$, the strength did not meet the requirements, which often lead to unsafe factors. However, for inorganic salts $C B, N B, N N$, and $\mathrm{CN}$, although the compressive strength with the increase of the inorganic salt content was greater than that of AS experiment group, only the 1-d compressive strength of the mortar mixed with 1.5\% NB and 1.5\% NN exceeded the requirements of GB/T 3519-2017 ( $8 \mathrm{MPa}$ ) by $12.85 \%$ and $11.8 \%$, respectively. Figure $3 \mathrm{~B}$ describes the effects of different dosages of inorganic salts on the 3 -d compressive strength of the mortar. The data showed that the compressive strength of each experimental group increased continuously, higher than that of the AS experimental group (10.04 MPa). However, the mortar compressive strength of the blank group (AS) was $31.65 \mathrm{MPa}$ at the age of $7 \mathrm{~d}$, which was higher than that of the experimental group mixed with the inorganic salts partially. The results are shown in Figure 3C. Therefore, it could be explained that the effects of the low-temperature environment and inorganic salts on hydration were mainly concentrated in the 1 and $3 \mathrm{~d}$ of early age. With the extension of the curing period, the effects of the low-temperature environment and inorganic salts on hydration gradually disappeared. In Figure 3D, the 28-d compressive strength of the group mixed with $1 \%$ CB and $1 \%$ NB was slightly higher than that of the AS experimental group. Under different dosage of other inorganic salts, the 28-d compressive strength shrank to varying degrees, and the shrinkage of the CN and 
$\mathrm{NN}$ experimental groups was the most remarkable. It might be mainly due to the reaction between nitrate and $\mathrm{C}_{3} \mathrm{~A}$ in cement to form needle nitrate hydrate, which showed brittle fracture behavior [22,26]. Combined with Figures 4-6, it could be seen that the inorganic salt NN had an excellent promoting effect on the early 1-d compressive strength, but its later strength shrinkage was pronounced, while NB overcame the problem of the later strength shrinkage.
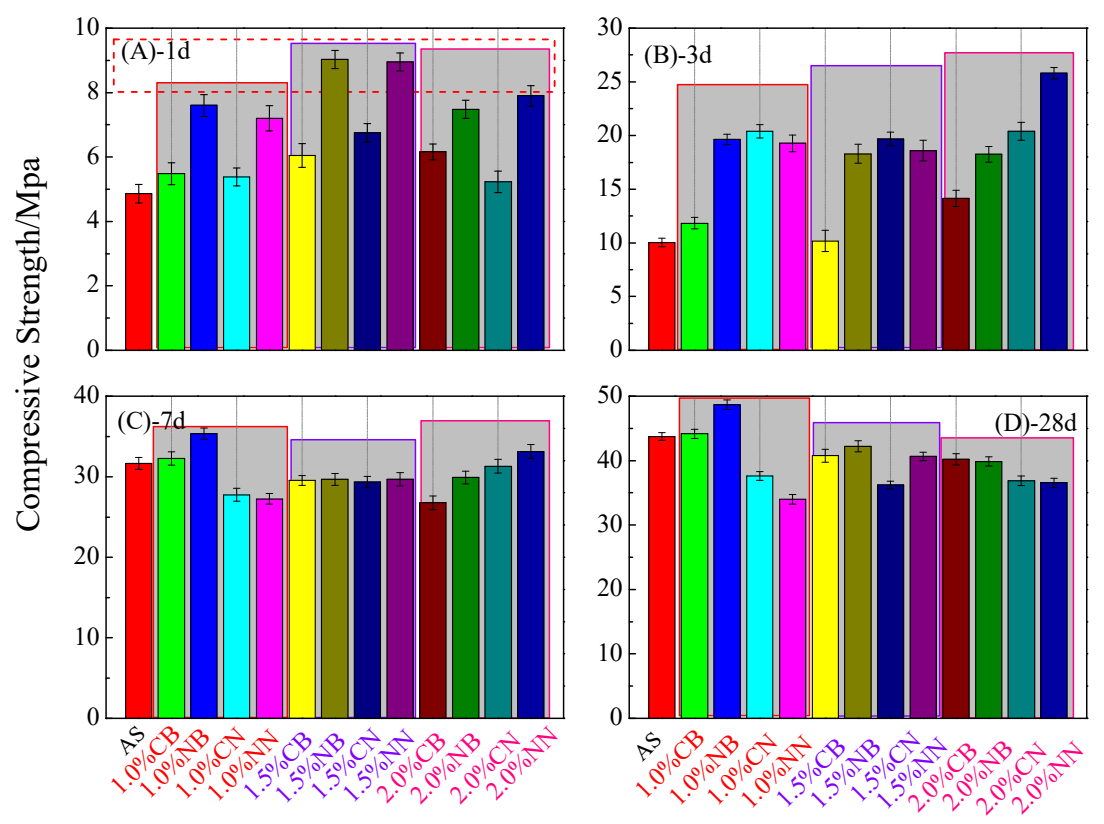

Figure 3. Effects of inorganic salts on the strength at $10^{\circ} \mathrm{C}$ : (A) curing for 1 day; (B) curing for 3 days; (C) curing for 7 days; (D) curing for 28 days.

\subsection{Hydration Heat in the Low-Temperature Environment}

The hydration temperature of cement could reflect the hydration process of water. The hydration temperature of cement after adding inorganic salts was tested, as shown in Figure 4; It could be seen that the second peak hydration temperature of the cement paste without inorganic salts was the lowest, and the hydration temperature of the cement paste with $1.5 \%$ NB could reach $13.8^{\circ} \mathrm{C}$, as shown in Figure $4 \mathrm{~A}$. In Figure $4 \mathrm{~B}$, with $1.0 \% \mathrm{NN}$, the hydration temperature of the cement paste could arrive at $14.1^{\circ} \mathrm{C}$. At the same time, in order to reduce the error caused by the experimental operation, the influence of inorganic salts on the hydration temperature of the cement paste was comprehensively evaluated. According to Equation (1), the hydration temperature was calculated as the evaluation basis:

$$
T_{\text {evaluation }}=\frac{1}{3} \sum_{i j} T_{i j} \quad(i=1 \%, 1.5 \%, 2 \%, j=X),
$$

where $T_{\text {evaluation }}$ is the average of the temperature peaks that occur during hydration, $X$ stands for different inorganic salts $\mathrm{CN}, \mathrm{NN}, \mathrm{CB}$, and $\mathrm{NB}$, and $T_{\text {evaluation }}$ represents the average temperature of the three peak temperatures during hydration.

The temperature calculated by Equation (1) was used as the basis for evaluating the hydration of the cement paste by inorganic salts. However, the hydration temperature and the heat of hydration were equivalent and could be calculated for each other. The hydration temperature calculated from the heat release is shown as Equation (2) [27]:

$$
T_{\text {evaluation }}=Q_{T_{\text {evaluation }}} \times \frac{m_{C}}{C}+T_{0},
$$

where $T_{0}$ is the initial temperature of the raw material, $C$ is the specific heat of the cement paste, and $m_{C}$ is the hydrated mass of the phase at $T_{\text {evaluation. }}$. 


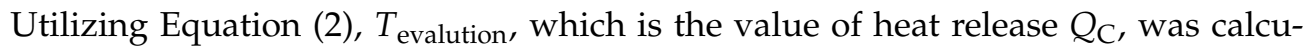
lated. $Q_{\text {Tevaluation, }}$ as the heat of hydration of phase at time $T_{\text {evaluation, was described as }}$ Equation (3):

$$
\begin{gathered}
Q_{T_{\text {evaluation }}}=\frac{\left(T_{\text {evaluation }}-T_{0}\right) \times C}{m_{C}}, \\
\alpha_{T(\text { evaluation })} \times Q^{\max }=\left(T_{\text {evaluation }}-T_{0}\right) \times \frac{C}{m_{C}},
\end{gathered}
$$

where $\alpha_{\mathrm{T}(\text { evaluation) }}$ is the degree of hydration of the phase at $T_{\text {evaluation }}, Q_{\max }$ is the released heat of the phase at complete hydration. The calculation results from Equations (1) and (4) are shown in Table 6.

\begin{tabular}{|c|c|c|c|c|c|c|c|c|}
\hline $\begin{array}{c}\text { Inorganic } \\
\text { Salt }\end{array}$ & & $T_{\mathrm{ij}}\left({ }^{\circ} \mathrm{C}\right)$ & & $\begin{array}{c}T_{\text {evaluation }} \\
\quad\left({ }^{\circ} \mathrm{C}\right)\end{array}$ & $T_{0}\left({ }^{\circ} \mathrm{C}\right)$ & $\Delta T\left({ }^{\circ} \mathrm{C}\right)$ & $\alpha_{\mathrm{T}(\text { evaluation })}$ & $Q_{\max }$ \\
\hline AS & & 11.2 & & 11.2 & 10 & 1.2 & Min & The maximum heat \\
\hline $\mathrm{CB}$ & 12.8 & 11.8 & 12.5 & 12.3 & 10 & 2.3 & $\alpha_{\mathrm{AS}}+\mathrm{CB}>\alpha_{\mathrm{AS}}+\mathrm{CN}$ & release was equal, \\
\hline NB & 13.5 & 14.2 & 13.7 & 13.8 & 10 & 3.8 & $\alpha_{\mathrm{AS}}+\mathrm{NB}>\alpha_{\mathrm{AS}}+\mathrm{CB}$ & because the hydrated \\
\hline $\mathrm{NN}$ & 14.8 & 14.2 & 13.2 & 14.1 & 10 & 4.1 & Max & substance was \\
\hline $\mathrm{CN}$ & 11 & 11.5 & 12.6 & 11.7 & 10 & 1.7 & $\alpha_{\mathrm{AS}+\mathrm{CN}}>\alpha_{\mathrm{AS}}$ & completely hydrated. \\
\hline
\end{tabular}

Table 6. Hydration-related parameters.
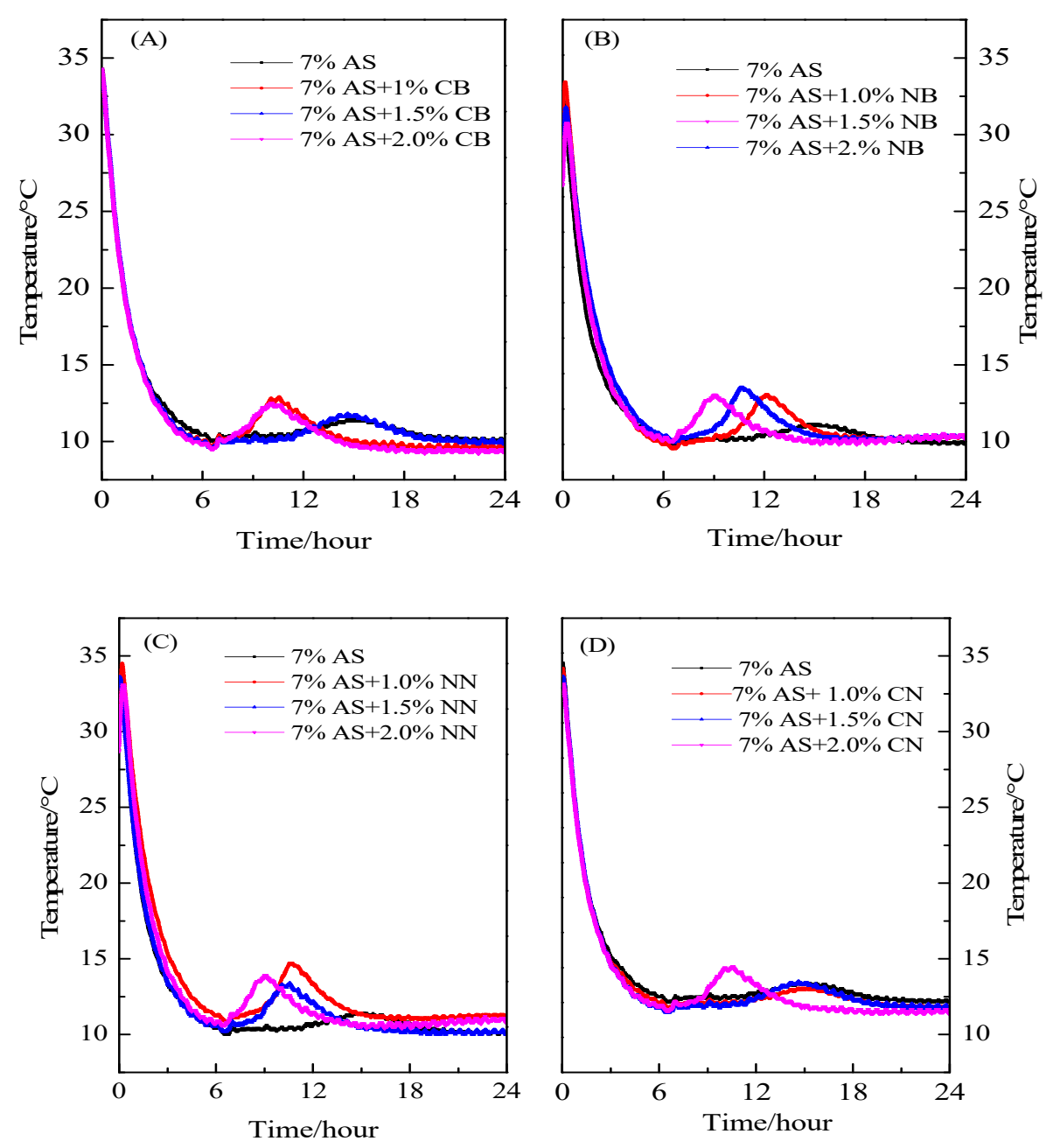

Figure 4. Heat of hydration of different inorganic salts at $10{ }^{\circ} \mathrm{C}$ : (A) the different dosage of $\mathrm{CB}$; $(\mathbf{B})$ the different dosage of NB; (C) the different dosage of NN; (D) the different dosage of $\mathrm{CN}$. 
From the calculation results in Table 5, it could be seen that the degree of NN promoting hydration was the largest, that of NB was the second largest, and that of AS was the smallest. In addition, the second peak of the hydration heat flow curve was corresponding to the time of the maximum hydration temperature peak in Figure 5, which could be seen in the relevant literature $[28,29]$, which indicated that $\mathrm{NN}, \mathrm{NB}, \mathrm{CB}$, and $\mathrm{CN}$ promoted the hydration of $\mathrm{C}_{3} \mathrm{~S}$, thus accelerating the hydration and improving the early strength. In addition, the hydration time of the second hydration peak indicated NB and NN could accelerate the hydration in advance, shorten the hydration time and promote the second hydration peak to reach the peak. However, the hydration effects of NN and NB were significantly than those of $\mathrm{CB}$ and $\mathrm{CN}$. The results were consistent with the strength data in Figure 3.
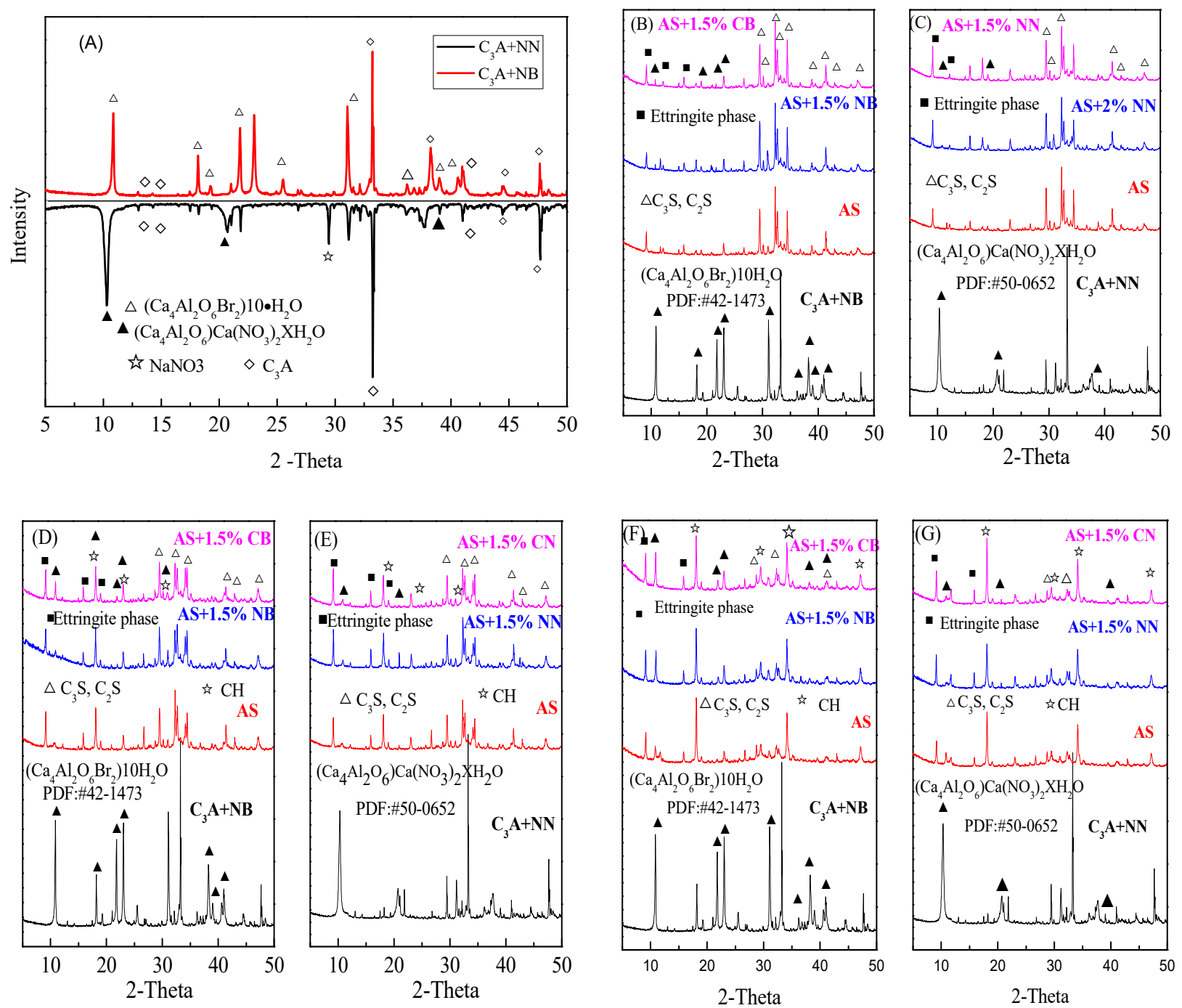

Figure 5. XRD of hydration products: (A) $C_{3} A+$ nitrate ions and $C_{3} A+$ bromine ions hydrated samples; (B) hydration product of the cement paste added with bromide for $12 \mathrm{~h}$; (C) hydration product of the cement paste added with nitrate for $12 \mathrm{~h}$; (D) hydration product of the cement paste added with bromide for $24 \mathrm{~h}$; (E) hydration product of the cement paste added with nitrate for $24 \mathrm{~h}$; (F) hydration product of the cement paste added with bromide for $28 \mathrm{~d} ;(\mathrm{G})$ hydration product of the cement paste added with nitrate for $28 \mathrm{~d}$.

\subsection{XRD Analysis}

It was verified that nitrate and bromide could participate in hydration reaction, according to the experimental method in Section 2.3. 
As shown in Figure 5A, it was evident that $\mathrm{C}_{3} \mathrm{~A}$ reacted with nitrate and bromide to form calcium aluminate phase substances $\left(\mathrm{Ca}_{4} \mathrm{Al}_{2} \mathrm{O}_{6} \mathrm{Br}_{2} \cdot 10 \mathrm{H}_{2} \mathrm{O}\right.$ (PDF\#:42-1473) and $3 \mathrm{CaOAl}_{2} \mathrm{O}_{3} \mathrm{Ca}\left(\mathrm{NO}_{3}\right)_{2} \mathrm{X} \cdot \mathrm{H}_{2} \mathrm{O}$ (PDF\#:50-0652), respectively.

The reaction results were consistent with the phase products of $\mathrm{C}_{3} \mathrm{~A}$ and calcium aluminate formed by nitrate and bromide reported in the relevant literature, and it was explained why this salt could shorten the setting time [13,20,23].

In Figure 5B, the hydration product of the cement paste with $2 \% \mathrm{CB}$ and $2 \% \mathrm{NB}$ cured at low temperature for $12 \mathrm{~h}$ was different from that of the cement paste without $\mathrm{CB}$ and NB. The appearing diffraction peak of $\mathrm{Ca}_{4} \mathrm{Al}_{2} \mathrm{O}_{6} \mathrm{Br}_{2} 10 \mathrm{H}_{2} \mathrm{O}$ indicated that bromine ions participated in the hydration of $\mathrm{C}_{3} \mathrm{~A}$, which was similar to $\mathrm{AFt}$ and played a role in promoting the paste condensation. In addition, the diffraction peak of $\mathrm{CH}$ was weak in hydration products, and the degree of hydration was not high. In Figure 5C, compared with the AS group, $3 \mathrm{CaOAl}_{2} \mathrm{O}_{3} \mathrm{Ca}\left(\mathrm{NO}_{3}\right)_{2} \mathrm{X} \cdot \mathrm{H}_{2} \mathrm{O}$ formed when added with $2 \% \mathrm{CN}$ and $2 \%$ $\mathrm{NN}$ in $12 \mathrm{~h}$ for hydration. Meanwhile, the diffraction peak of the hydration product $\mathrm{CH}$ (added with $2 \% \mathrm{NN}$ ) was more potent than that of $2 \% \mathrm{CN}$, indicating that the hydration promoted by $\mathrm{NN}$ was significantly more potent than that of $\mathrm{CN}$, which was consistent with the 1-d compressive strength in Figure 3.

In Figure 5D, compared with the AS group, the diffraction peaks of $\mathrm{Ca}_{4} \mathrm{Al}_{2} \mathrm{O}_{6} \mathrm{Br}_{2} 10 \mathrm{H}_{2} \mathrm{O}$ and $\mathrm{CH}$ increased significantly when adding the inorganic salt NN. However, for the AS group, the diffraction peak of $\mathrm{C}_{3} \mathrm{~S}$ was higher than those of the NB and $\mathrm{CB}$ groups. Therefore, it could be inferred that the addition of bromine-containing inorganic salts did promote the dissolution and hydration of $C_{3} S$, consistent with the description in the literature [13].

In Figure 5E, the law was similar to Figure 5D. Therefore, the comprehensive analysis of hydration products showed that inorganic salts containing bromine and nitrate could form a new aluminate phase. In addition, the degree of hydration decreased gradually with the passage of hydration time. Therefore, the hydration products of 28 days were further investigated, as shown in Figure 5E,F. It could be seen that the peak intensities of $C_{3} S$ and $\mathrm{CH}$ hydration characteristic peaks were roughly the same in the hydration products of $28 \mathrm{~d}$, indicating that the degree of hydration remained the same no matter whether inorganic salt was added or not at 28 days. The comprehensive evaluation analysis of all figures in Figure 5 showed that inorganic salts significantly impacted hydration during $12-24 \mathrm{~h}$ of hydration, reflecting the conclusion of the strength data. With the progress of hydration, the disparity was gradually narrowed.

Thus, it could be seen that the low-temperature environment mainly affected early performance. The addition of inorganic salts could significantly improve the early $(0-24 \mathrm{~h})$ hydration reaction rate of mortar added, making it meet the requirements of low-temperature construction (setting time and early strength).

\subsection{Thermogravimetric Analysis}

In this experiment, the thermal weight changes of hydration products of the cement paste were measured at $12 \mathrm{~h}, 24 \mathrm{~h}$, and $28 \mathrm{~d}$ of hydration added with $1.5 \% \mathrm{CB}, 1.5 \%$ $\mathrm{NB}, 1.5 \% \mathrm{CN}$, and $1.5 \% \mathrm{NN}$. The amount of the bound water (BW) was compared in each case, and the hydrate products were determined. The samples were heated in the range of $30-1000{ }^{\circ} \mathrm{C}$ at a $20^{\circ} \mathrm{C} / \mathrm{min}$ heating rate. The contents of the chemical $\mathrm{BW}$ of all hydration products and $\mathrm{CH}$ were calculated according to the mass loss [30-32]. As shown in Figure 6A, added with 1.5\% CB and 1.5\% NB in the sample, the mass reduction peak could be observed at the temperature of $90-120{ }^{\circ} \mathrm{C}$. The main reason for the mass reduction was the removal of $\mathrm{BW}$ from the ettringite phase in this temperature range. The production of the ettringite phase mainly originated from two aspects: (1) a ettringite phase was produced by the alkali-free accelerator; (2) a ettringite phase was produced by the reaction of bromine ions and nitrate ions with $\mathrm{C}_{3} \mathrm{~A}$ separately. For the AS experimental group, the ettringite phase originated from the alkali-free accelerator reation with $\mathrm{C}_{3} \mathrm{~A}$. However, for the inorganic salts experimental groups, i.e., $\mathrm{AS}+1.5 \% \mathrm{CB}$ and $\mathrm{AS}+1.5 \%$ $\mathrm{NB}$, the mass of the ettringite phase was the sum mainly produced by the accelerator, $\mathrm{C}_{3} \mathrm{~A}$, 
and the inorganic salt Therefore, the results showed that the mass losses of the inorganic salts experimental groups were greater than that of the AS experimental group. It was consistent with the results of Figure 4A,B. In addition, it could be observed that there were a mass loss peak of $\mathrm{CH}$ in the samples mixed with $\mathrm{CB}$ and $\mathrm{NB}$ at $300-450{ }^{\circ} \mathrm{C}$; however, a mass loss peak of $\mathrm{CH}$ in the AS experimental group did not appear. Therefore, these phenomena could be explained by the fact that inorganic salts promoted the hydration reaction of cement in the early stage $(12 \mathrm{~h})$.

In Figure 6B, the mass loss of the experimental group with $1.5 \% \mathrm{CN}$ and $1.5 \% \mathrm{NN}$ was greater than that of the AS experimental group at $90-120{ }^{\circ} \mathrm{C}$. The reason for this phenomena was the same as that used to explain the results in Figure 6A. An increased mass loss appeared on this temperature range. At the same time, it was observed that the mass loss of $\mathrm{CH}$ was greater than those of $\mathrm{CB}$ and $\mathrm{NB}$ at $300-450{ }^{\circ} \mathrm{C}$, indicating that the hydration-promoting effects of $\mathrm{CN}$ and $\mathrm{NN}$ were slightly greater than those of $\mathrm{CB}$ and $\mathrm{NB}$ at $12 \mathrm{~h}$ of the cement hydration reaction.

With the progress of hydration, the tested cement samples were hydrated for $24 \mathrm{~h}$, as shown in Figure $6 \mathrm{C}, \mathrm{D}$. The results showed that the mass loss of the ettringite phase gradually decreased in the AS experimental groups at $90-120^{\circ} \mathrm{C}$, while the mass loss of $\mathrm{CH}$ also decreased. When inorganic salts were added in the experimental groups, the amount of $\mathrm{CH}$ hydration products increased and the hydration was dominant. The conclusion was consistent with the 1-d compressive strength test results in Figure 3.

According to the mass losses of the hydration products in $28 \mathrm{~d}$ shown in Figure $6 \mathrm{E}, \mathrm{F}$, it could be seen that the mass losses of the ettringite phase were almost similar at $90-120{ }^{\circ} \mathrm{C}$, and the mass loss peak of $\mathrm{CH}$ was almost the same as that of the AS experimental group at $300-450{ }^{\circ} \mathrm{C}$. The main reason was that the amount of combined water formed by bromine ions and nitrate ions in the bromine-ettringite phase and the nitrate-ettringite phase, less than that in ettringite formed by $\mathrm{AS}$ and $\mathrm{C}_{3} \mathrm{~A}$. Therefore, there was a little difference in quality loss. However, the main ettringite phase was dominated by the nitrate-ettringite and bromine-ettringite phases in the early stage of hydration (12 and $24 \mathrm{~h}$ ).

Combined with the TG/DTG data, the contents of ettringite and $\mathrm{CH}$ in the system were calculated. The calculation results are shown in Figure 7. BW was the bound water of all hydration products except $\mathrm{CH}$. BW and $\mathrm{CH}$ were calculated as the following Equations (5) and (6), respectively [13]:

$$
\begin{gathered}
\mathrm{CH}=\frac{74}{18} \times \frac{M_{400 \mathrm{C}}-M_{470 \mathrm{C}}}{M_{550 \mathrm{C}}} \times 100 \%, \\
\mathrm{BW}=\left[\frac{M_{50 \mathrm{C}}-M_{550 \mathrm{C}}}{M_{550 \mathrm{C}}}-\frac{M_{400 \mathrm{C}}-M_{470 \mathrm{C}}}{M_{550 \mathrm{C}}}\right] \times 100 \%,
\end{gathered}
$$

where BW represents the bound water content of all hydration products except $\mathrm{CH}$, and the product $\mathrm{CH}$ represents the content of Portland stone; $M_{50}{ }^{\circ} \mathrm{C}, M_{400}{ }^{\circ} \mathrm{C}, M_{470^{\circ} \mathrm{C}}$, and $M_{550^{\circ} \mathrm{C}}$ indicate that the masses of the sample at temperatures of $50,400,470$, and $550{ }^{\circ} \mathrm{C}$, respectively.

It could be seen from the calculation results that the content of $\mathrm{CH}$ in the hydration product of the AS experimental group was lower than those of inorganic salt components at 12 and 24 h, as shown in Figure 7A. However, the $\mathrm{CH}$ content was higher at $28 \mathrm{~d}$, consistent with the experimental group mixed with inorganic salts, and the results could identify with the mortar strength data in Figure 3. However, as shown in Figure 7B, the combined water of hydration products of components was more significant than that added with inorganic salts at $12 \mathrm{~h}$ in the AS experimental group, which could explain that inorganic salts promoted hydration and their products might contain two or more kinds of AFt, nitrate-AFt, bromide-AFt, and CSH. 

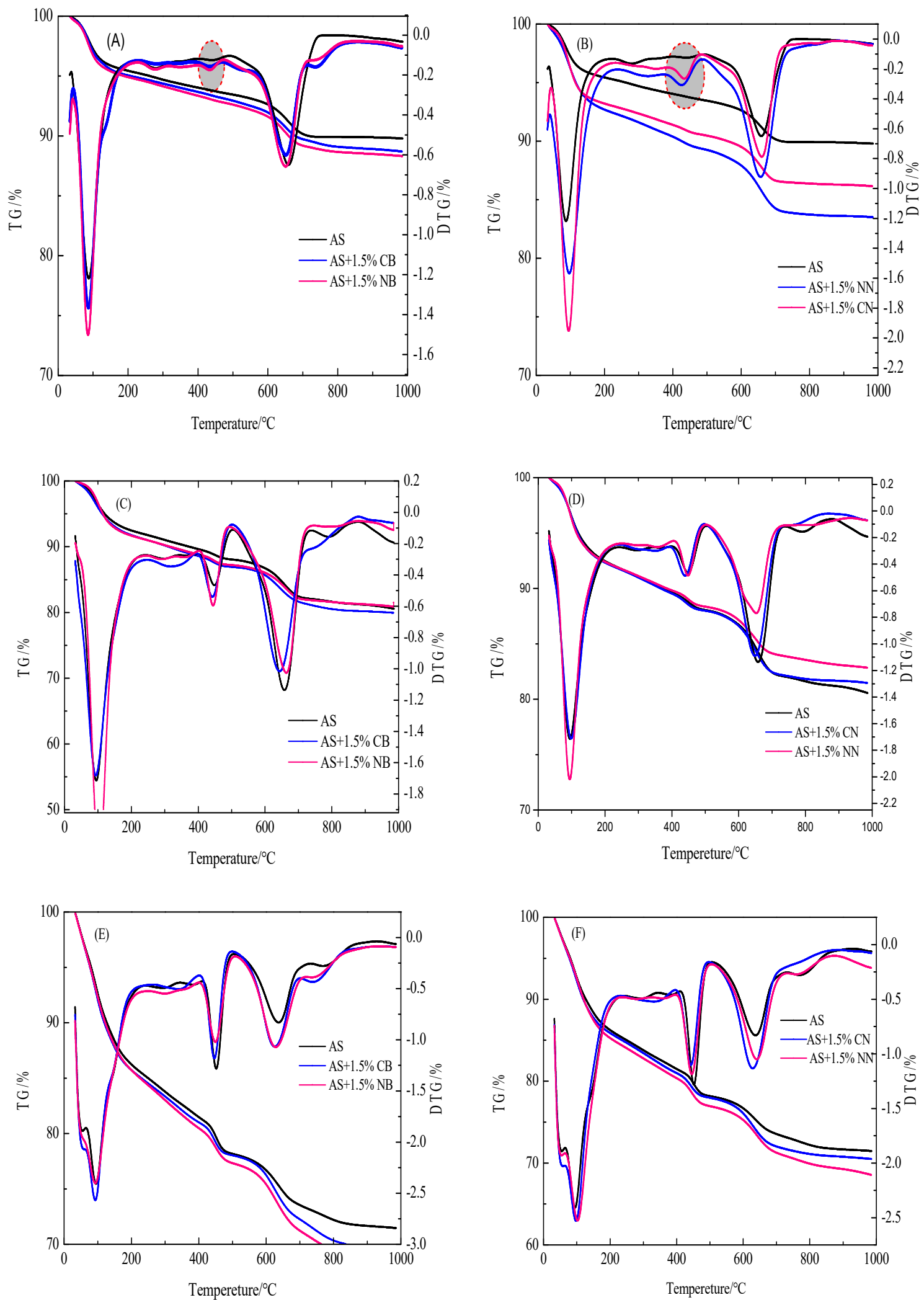

Figure 6. DG/DTG of hydration products: $(\mathbf{A}, \mathbf{B})$ hydration products of the cement paste added with $\mathrm{CB} / \mathrm{CN}$ and NB/NN for $12 \mathrm{~h}$; (C,D) hydration products of the cement paste added with $\mathrm{CB} / \mathrm{CN}$ and NB/NN for $24 \mathrm{~h}$; (E,F) hydration products of the cement paste added with $\mathrm{CB} / \mathrm{CN}$ and NB/NN for $28 \mathrm{~d}$. 

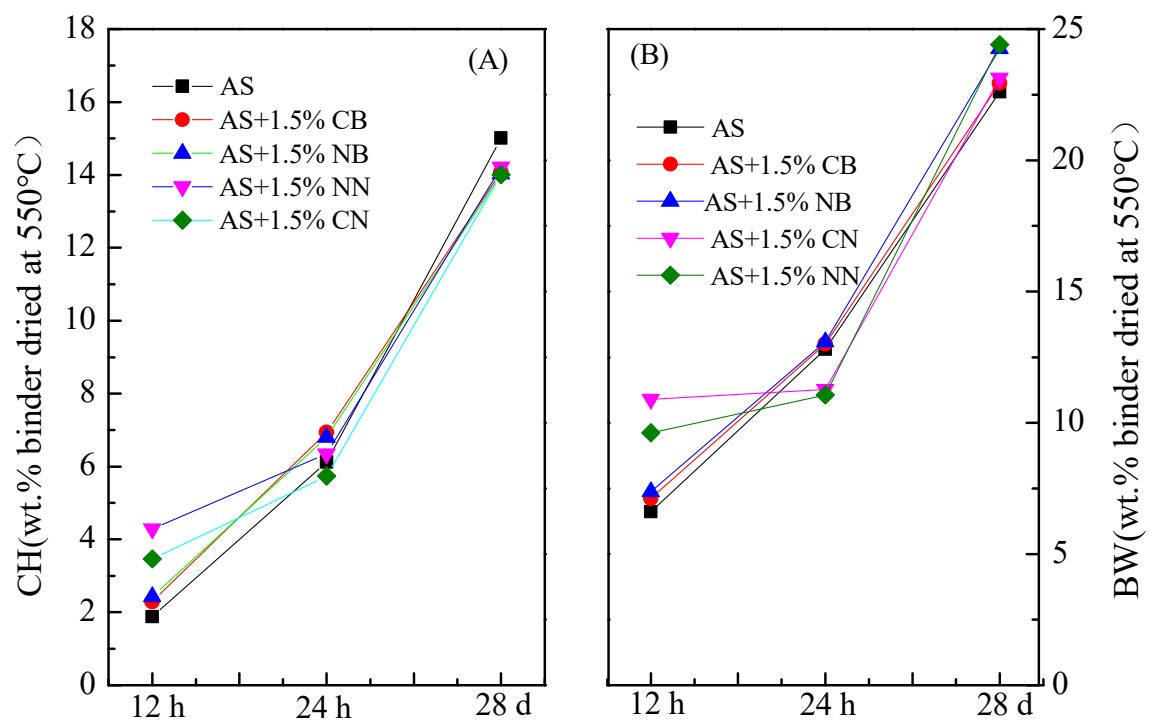

Figure 7. Hydration products of different systems at $10{ }^{\circ} \mathrm{C}$ : (A) $\mathrm{CH}(\mathrm{wt} \%)$; (B) bound water (BW; wt \%).

Based on the XRD and TG test results, the hydration process diagram under a lowtemperature environment could be deduced, as shown in Figure 8. The hydration process was described as follows: $\mathrm{CB}, \mathrm{CN}, \mathrm{BN}, \mathrm{NN}$, and $\mathrm{C}_{3} \mathrm{~A}$ preferentially formed a bromideettringite phase and a nitrate-ettringite phase. When added the accelerator, $\mathrm{C}_{3} \mathrm{~A}$ of the cement system and the accelerator formed the ettringite phase, accelerated the hydration. At this time, the ettringite phase consisted of Aft, the bromide-ettringite phase, the nitrateettringite phase composition (the mass change in the range of $90-120^{\circ} \mathrm{C}$ could also be seen from the TG/DTG mass loss data) [32,33]. $\mathrm{CH}$ gradually formed (the strong $\mathrm{CH}$ diffraction peak with inorganic salts was more substantial than without inorganic salts). With the progress of hydration, the advantages of inorganic salts gradually disappeared ( $\mathrm{CH}$ diffraction peak and compressive strength data). It could be seen that the contribution of the inorganic salt synergetic accelerator was mainly concentrated in the early stage of hydration in a low-temperature environment.

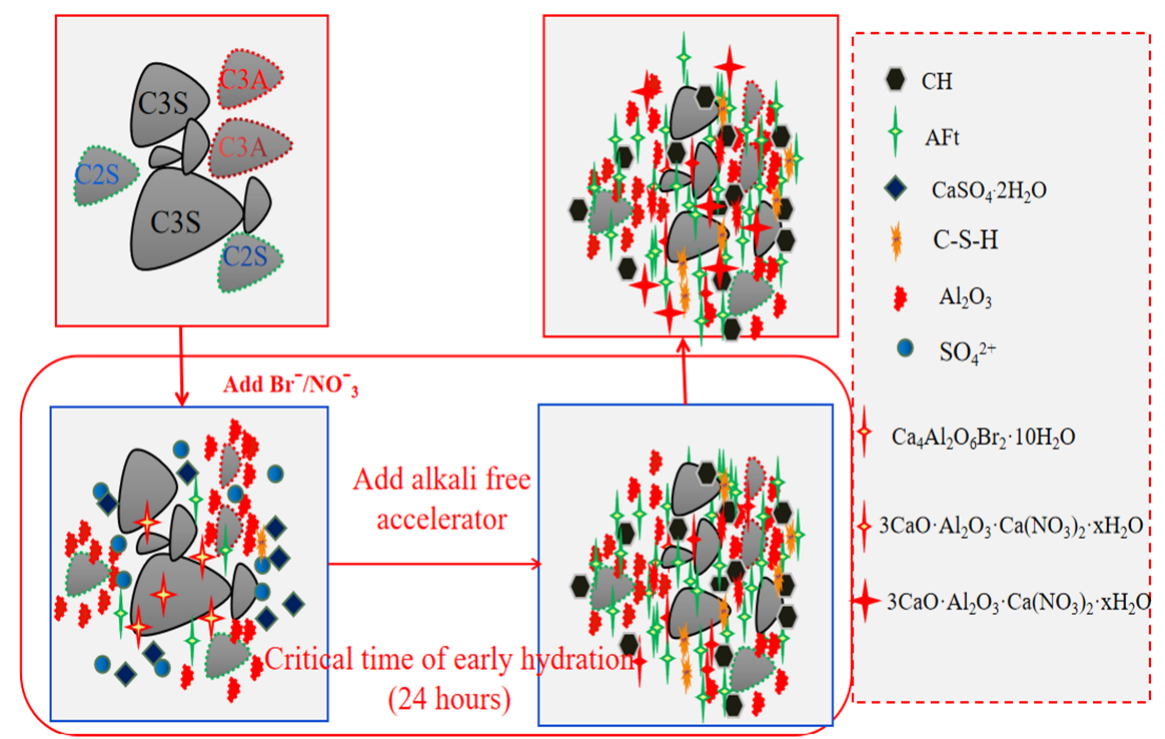

Figure 8. Schematic diagram of synergy. 


\subsection{SEM Analysis}

The hydration products produced by the alkali-free liquid accelerator system were analyzed by a scanning electron microscope. In Figure 9A, it could be observed that AS could also produce hydration products at $10^{\circ} \mathrm{C}$, which were mainly ettringite and C-S-H. Compared with that for $28 \mathrm{~d}$, the amount of hydration products was observably reduced. However, compared with the component added with an inorganic salt (Figure 8C,E,G,H), the hydration degree was prominently improved in $1 \mathrm{~d}$, of which $1.5 \% \mathrm{NN}$ and $1.5 \% \mathrm{NB}$ were relatively obvious. However, for the added inorganic salt components, the formation of new phases was the focus of attention.
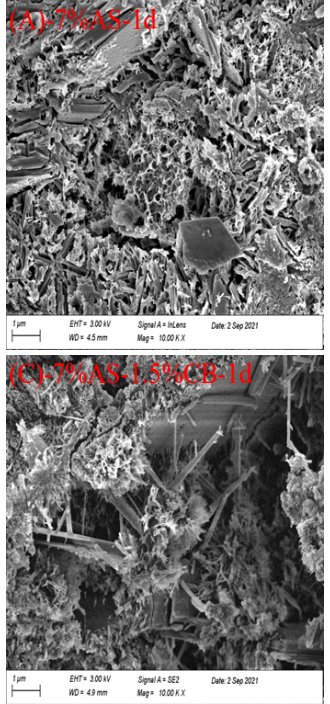
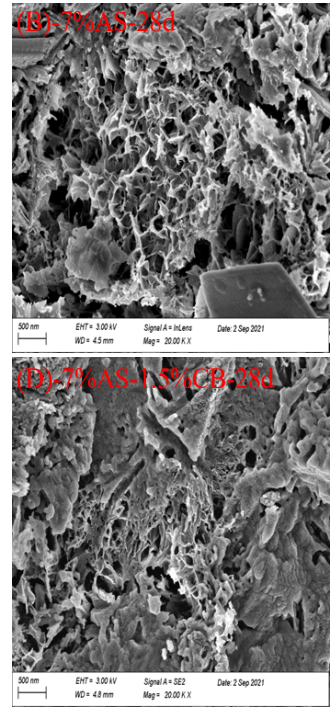
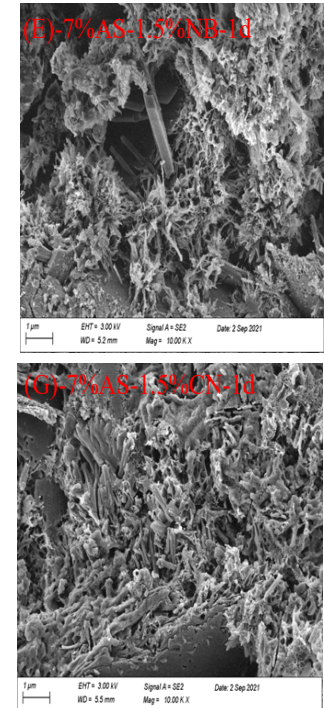
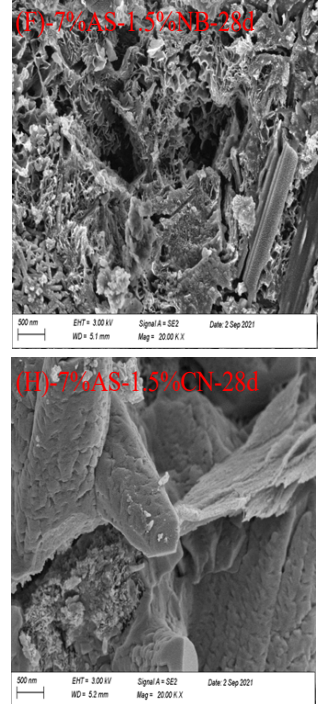
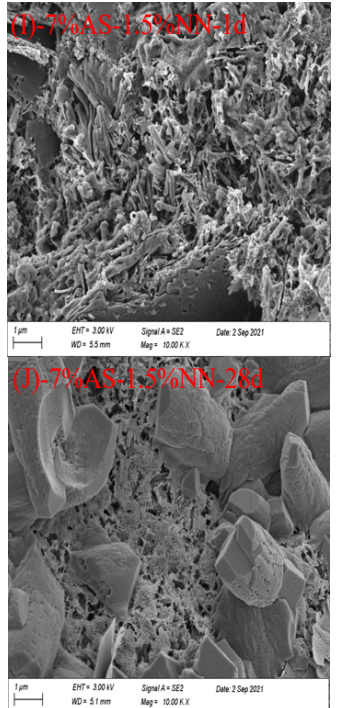

Figure 9. SEM patterns of samples: (A,B) hydration products of the cement paste added with $7 \%$ AS for $24 \mathrm{~h} / 28 \mathrm{~d}$; (C,D) hydration products of the cement paste added with $1.5 \%$ CB for $24 \mathrm{~h} / 28 \mathrm{~d} ;(\mathbf{E}, \mathbf{F})$ hydration products of the cement paste added with $1.5 \%$ NB for $24 \mathrm{~h} / 28 \mathrm{~d} ;(\mathbf{G}, \mathbf{H})$ hydration products of the cement paste added with $1.5 \% \mathrm{CN}$ for $24 \mathrm{~h} / 28 \mathrm{~d}$; (I,J) hydration products of the cement paste added with $1.5 \% \mathrm{NN}$ for $24 \mathrm{~h} / 28 \mathrm{~d}$.

According to the $X R D$ results of the hydration of $\mathrm{C}_{3} \mathrm{~A}$, inorganic salts, and the cement paste, the components of the new phase were $\mathrm{Ca}_{4} \mathrm{Al}_{2} \mathrm{O}_{3} 6 \mathrm{Br}_{2} 10 \cdot \mathrm{H}_{2} \mathrm{O}, 3 \mathrm{CaOAl}_{2} \mathrm{O}_{3} \mathrm{Ca}\left(\mathrm{NO}_{3}\right)_{2} \mathrm{X} \cdot \mathrm{H}_{2} \mathrm{O}$. By the SEM analysis in Figure 8, the new phase formed by bromide could hardly be found. The main reasons might be two aspects: (a) the new phase was covered by the hydration products, failing to be reflected in the figure; (b) the new phase crystal grew slowly or stably and did not increase bulk with the extension of hydration time, and the strength of the bromide inorganic salt did not shrink back in the later stage. For the system added with nitrate, the formation of a new phase could be observed obviously, and the formation of thick rod ellipsoid was observed in Figure 9J. However, the product was not evident in $1 \mathrm{~d}$, mainly concentrated in 28 days of hydration. Therefore, it was inferred that the crystal growth and expansion process could promote the early mechanical strength of the mortar and gradually show adverse effects later. It was consistent with the influence law of adding nitrate on the mechanical strength of the mortar in Figure 3.

\section{Conclusions}

The purpose of this paper was to investigate the effects of inorganic salts $\left(\mathrm{CaBr}_{2}\right.$, $\mathrm{NaBr}, \mathrm{Ca}\left(\mathrm{NO}_{3}\right)_{2}$, and $\left.\mathrm{NaNO}_{3}\right)$ on the hydration products, microstructure, and mechanical strength of mortar at $10^{\circ} \mathrm{C}$. The main results were as follows:

(1) The effects of inorganic salts $\mathrm{CB}, \mathrm{NB}, \mathrm{CN}$, and $\mathrm{NN}$ mixed with an alkali-free liquid accelerator on the comperssive strength and the setting time of mortar at $10{ }^{\circ} \mathrm{C}$ were studied. The 1-d comperssive strength of the AS experimental group was 4.17 MPa. 
When $1.5 \% \mathrm{NB}$ and $1.5 \% \mathrm{NN}$ were added to the cement, the 1-d compressive strength growth rates were $185.8 \%$ and $184.2 \%$, respectively. The final setting time of the AS experimental group was $7.74 \mathrm{~min}$. When $1.5 \% \mathrm{NB}$ and $1.5 \% \mathrm{NN}$ were added, the final setting time was shortened to 6.08 and $6.12 \mathrm{~min}$, respectively, so as to ensure that the alkali-free liquid accelerator met the requirements of GB/T 35159-2017 at low temperature.

(2) $\mathrm{C}_{3} \mathrm{~A}$ reacted with nitrate and bromine to form the nitrate-ettringite phase $\left(3 \mathrm{CaOAl}_{2} \mathrm{O}_{3} \mathrm{Ca}\left(\mathrm{NO}_{3}\right)_{2} \mathrm{X} \cdot \mathrm{H}_{2} \mathrm{O}\right)$ and the bromine-ettringite phase $\left(\mathrm{Ca}_{4} \mathrm{Al}_{2} \mathrm{O}_{6} \mathrm{Br}_{2} 10 \mathrm{H}_{2} \mathrm{O}\right)$. In addition, the hydration products hydrated for $12 \mathrm{~h}, 24 \mathrm{~h}$, and $28 \mathrm{~d}$ were analyzed in the cement paste mixed with inorganic salts and the accelerator, and $3 \mathrm{CaOAl}_{2} \mathrm{O}_{3} \mathrm{Ca}\left(\mathrm{NO}_{3}\right)_{2} \mathrm{X} \cdot \mathrm{H}_{2} \mathrm{O}$ and $\mathrm{Ca}_{4} \mathrm{Al}_{2} \mathrm{O}_{6} \mathrm{Br}_{2} 10 \cdot \mathrm{H}_{2} \mathrm{O}$ were detected. The mass loss of the ettringite phase at $90-120{ }^{\circ} \mathrm{C}$ was analyzed by TG/DTG. The comprehensive TG and XRD analyses showed that the ettringite phase were composed of $\mathrm{AFt}$, $3 \mathrm{CaOAl}_{2} \mathrm{O}_{3} \mathrm{Ca}\left(\mathrm{NO}_{3}\right)_{2} \mathrm{X} \cdot \mathrm{H}_{2} \mathrm{O}$, and $\mathrm{Ca}_{4} \mathrm{Al}_{2} \mathrm{O}_{6} \mathrm{Br}_{2} 10 \cdot \mathrm{H}_{2} \mathrm{O}$. This stage had a positive contribution to the early strength of the cement, but its contribution gradually weakened in the later stage of the cement hydration.

(3) A test multi-channel temperature collector was used to collect the hydration temperature in the hydration process with different dosage of the accelerator at $10{ }^{\circ} \mathrm{C}$. Through calculation, the influence relationships between the inorganic salts and the alkali-free liquid accelerator on the hydration degree were as follows: $\alpha_{\mathrm{AS}}+\mathrm{NN}>$ $\alpha_{\mathrm{AS}+\mathrm{NB}}>\alpha_{\mathrm{AS}+\mathrm{CB}}>\alpha_{\mathrm{AS}+\mathrm{CN}}>\alpha_{\mathrm{AS}}$. At the same time, combined with the influence of inorganic salts on the mortar compressive strength, it was comprehensively analyzed that when the dosage was $1.5 \% \mathrm{NN}$ and $1.5 \% \mathrm{NB}$, it had the greatest influence on the hydration degree.

Author Contributions: Experiment, result analysis, and data processing, Y.X.; conceptualization, resources, funding acquisition, data curation, and reviewing and editing, T.H. All authors have read and agreed to the published version of the manuscript.

Funding: This research was funded by the Lei Zhi Innovation Fund project (grant number: JYGrp20190501).

Data Availability Statement: Not applicable.

Acknowledgments: The authors were grateful to the Xiamen Academy of Building Research Group Co., Ltd. This research was funded by the Lei Zhi Innovation Fund project (JYGrp20190501).

Conflicts of Interest: The authors declare that they have no known competing financial interest or personal relationships that could have appeared to influence the work reported in this paper.

\section{References}

1. Tang, Y.; Xu, G.; Lian, J.; Su, H.; Qu, C. Effect of temperature and humidity on the adhesion strength and damage mechanism of shotcrete-surrounded rock. Constr. Build. Mater. 2016, 124, 1109-1119. [CrossRef]

2. Prudêncio, L.R. Accelerating admixtures for shotcrete. Cem. Concr. Compos. 1998, 20, 213-219. [CrossRef]

3. Han, J.; Wang, K.; Shi, J.; Wang, Y. Influence of sodium aluminate on cement hydration and concrete properties. Constr. Build. Mater. 2014, 64, 342-349. [CrossRef]

4. Salvador, R.P.; Cavalaro, S.H.; Segura, I.; Figueiredo, A.D.; Pérez, J. Early age hydration of cement pastes with alkaline and alkali-free accelerators for sprayed concrete. Constr. Build. Mater. 2016, 111, 386-398. [CrossRef]

5. Wang, Y.; Shi, C.; Ma, Y.; Xiao, Y.; Liu, Y. Accelerators for shotcrete-Chemical composition and their effects on hydration, microstructure and properties of cement-based materials. Constr. Build. Mater. 2021, 281, 122557. [CrossRef]

6. Mehta, P.K.; Monteiro, P.J.M. Concrete: Microstructure, Properties, and Materials, 3rd ed.; McGraw-Hill: New York, NY, USA, 2006.

7. Popovics, S. (Ed.) Concrete Materials_Properties, Specifications and Testing, 2nd ed.; William Andrew Publwashing: Norwich, NY, USA, 1992; pp. 236-246.

8. The Americould Concrete Institute. Committee Report ACI 212.3R-04, Chemical Admixtures for Concrete; The Americould Concrete Institute: Farmington Hills, MI, USA, 2004.

9. Taylor, H.F.W. Cement Chemwastry; Academic Press Limited: London, UK, 1990; Chapter 11; pp. 358-359.

10. Lee, T.; Lee, J.; Kim, Y. Effects of admixtures and accelerators on the development of concrete strength for horizontal form removal upon curing at $10{ }^{\circ} \mathrm{C}$. Constr. Build. Mater. 2020, 237, 117652. [CrossRef] 
11. Niu, D.; Zhang, S.; Wang, Y.; Hong, M.; Li, Z. Effect of temperature on the strength, hydration products and microstructure of shotcrete blended with supplementary cementitious materials. Constr. Build. Mater. 2020, 264, 120234. [CrossRef]

12. Zeng, X.; Ma, C.; Long, G.; Dang, H.; Xie, Y. Hydration kinetics of cement composites with different admixtures at low temperatures. Constr. Build. Mater. 2019, 225, 223-233. [CrossRef]

13. Zhang, F.; Bai, Y.; Cai, Y. Early strength and microstructure of Portland cement mixed with calcium bromide at $5{ }^{\circ} \mathrm{C}$. Constr. Build. Mater. 2020, 271, 121508. [CrossRef]

14. Bao, J.; Ren, Q.; Sun, L.; Ding, Y.; Oh, W.-C. Preparation of an Early Strengthening Agent for Concrete under Low-Temperature Conditions and Evaluation of Its Reaction Mechanism. Korean J. Mater. Res. 2021, 31, 195-208. [CrossRef]

15. Shi, Y.Z.; Wang, Q.; Song, P.; Jia, L.L. Advanced early strength agent development and mechanism analysis. Adv. Mater. Res. 2011, 261-263, 323-327. [CrossRef]

16. Wang, J.G.; Tong, A.Q.; Fan, Z.Z.; Liu, Q.W. The Performance Evaluation of New Low Temperature early Strength Agent ZL-1. Appl. Mech. Mater. 2014, 470, 842-846. [CrossRef]

17. Lee, T.; Lee, J.; Kim, J.; Choi, H.; Lee, D.-E. Effect of Formwork Removal Time Reduction on Construction Productivity Improvement by Mix Design of Early Strength Concrete. Appl. Sci. 2020, 10, 7046. [CrossRef]

18. Zou, D.; Wang, K.; Li, H.; Guan, X. Effect of LiAl-layered double hydroxides on hydration of calcium sulfoaluminate cement at low temperature. Constr. Build. Mater. 2019, 223, 910-917. [CrossRef]

19. Yoneyama, A.; Choi, H.; Inoue, M.; Kim, J.; Lim, M.; Sudoh, Y. Effect of a Nitrite/Nitrate-Based Accelerator on the Strength Development and Hydrate Formation in Cold-Weather Cementitious Materials. Materials 2021, 14, 1006. [CrossRef]

20. Kim, J.; Honda, D.; Choi, H.; Hama, Y. Investigation of the Relationship between Compressive Strength and Hydrate Formation Behavior of Low-Temperature Cured Cement upon Addition of a Nitrite-Based Accelerator. Materials 2019, 12, 3936. [CrossRef]

21. Liu, Z.; Lou, B.; Barbieri, D.M.; Sha, A.; Ye, T.; Li, Y. Effects of pre-curing treatment and chemical accelerators on Portland cement mortars at low temperature $\left(5^{\circ} \mathrm{C}\right)$. Constr. Build. Mater. 2020, 240, 117893. [CrossRef]

22. Balonwas, M.; Medala, M.; Glasser, F.P. Influence of calcium nitrate and nitrite on the constitution of AFm and AFt cement hydrates. Adv. Cem. Res. 2011, 23, 129-143. [CrossRef]

23. Suh, J.I.; Yum, W.S.; Song, H.; Park, H.-G.; Oh, J.E. Influence of calcium nitrate and sodium nitrate on strength development and properties in quicklime (CaO)-activated Class F fly ash system. Mater. Struct. 2019, 52, 115. [CrossRef]

24. Sargam, Y.; Wang, K. Hydration kinetics and activation energy of cement pastes containing various nanoparticles. Compos. Part $B$ Eng. 2021, 216, 108836. [CrossRef]

25. Xu, Q.; Hu, J.; Ruiz, J.M.; Wang, K.; Ge, Z. Isothermal calorimetry tests and modeling of cement hydration parameters. Thermochim. Acta 2010, 499, 91-99. [CrossRef]

26. Paulo, J.M. Concrete, Microstructure, Properties, and Materials, 2nd ed.; Mc Graw Hill: New York, NY, USA, $1995 ;$ pp. $181-227$.

27. D'aloia, L.; Chanvillard, G. Determining the "appwerent" activation energy of concrete: Ea-numerical simulations of the heat of hydration of cement. Cem. Concr. Res. 2002, 32, 1277-1289. [CrossRef]

28. Li, G.; Zhang, J.; Niu, M.; Song, Z. The mechanism of alkali-free liquid accelerator on the hydration of cement pastes. Constr. Build. Mater. 2020, 233, 117296. [CrossRef]

29. Yang, R.; He, T. The accelerating mechanism of alkali free liquid accelerator based on fluoroaluminate for shotcrete. Constr. Build. Mater. 2021, 274, 121830. [CrossRef]

30. Deschner, F.; Lothenbach, B.; Winnefeld, F.; Neubauer, J. Effect of temperature on the hydration of Portland cement blended with siliceous fly ash. Cem. Concr. Res. 2013, 52, 169-181. [CrossRef]

31. Guo, X.; Hu, W.; Shi, H. Microstructure and self-solidification/stabilization (S/S) of heavy metals of nano-modified CFA-MSWIFA composite geopolymers. Constr. Build. Mater. 2014, 56, 81-86. [CrossRef]

32. Balonwas, M. The Influence of Inorganic Chemical Accelerators and Corrosion Inhibitors on the Mineralogy of HydratedPortland Cement Systems. Ph.D. Thesis, University of Aberdeen, Aberdeen, UK, 2010.

33. Falzone, G.; Balonwas, M.; Sant, G. X-AFm stabilization as a mechanism of bypassing conversion phenomena in calcium aluminate cements. Cem. Concr. Res. 2015, 72, 54-68. [CrossRef] 